\title{
GREGORY PALAMAS' ONTOLOGY AS THEORETICAL FOUNDATION OF AXIOLOGICAL ASPECTS OF THE PHILOSOPHY OF „ALL-UNITY“
}

\author{
Iryna Kletskova - Anatoliy Lyahchylin
}

DOI: 10.17846/CL.2016.9.1.210-214

\begin{abstract}
KLETSKOVA, Iryna - LYAHCHYLIN, Anatoliy. Gregory Palamas' Ontology As Theoretical Foundation of Axiological Aspects of the Philosophy of "All-Unity". The influence of hesychastic traditions on the Russian culture can be found in cultural practices since the 15th century. In the 19th century, the tradition of hesychasm determined semantic coordinates of ontological aspects of the philosophy of "All-Unity“. This strategy is aimed at creation of unity which would have ontological basis. The idea of distinction of divine essence and divine energy offered by Gregory Palamas is the theoretical basis for the concept of the three divine Hypostases' and Sophia's correlation developed by V. S. Solovyov. The special ontological status of Sophia, its energies' nature, not only promotes creating harmonious and complete vision of life, but also gives to this life a special value status.
\end{abstract}

Key words: Hesychasm tradition, divine energy, Philosophy of „All-Unity” value status

\begin{abstract}
KLETSKOVA, Iryna - LYAHCHYLIN, Anatoliy. Ontológia Gregora Palamasa ako teoretický základ axiologických aspektov filozofie jednoty. Vplyv tradície hesychazmu na ruskú kultúru môžeme nájsț v kultúrnych prejavoch počnúc od 15. storočia. Od 19. storočia táto tradícia určuje sémantické súradnice ontologického aspektu filozofie "jednoty“. Táto stratégia je zameraná na vytvorenie jednoty, ktorá má ontologický status. Myšlienka rozlišovania božskej podstaty a božskej energie, ktorú ponúkol Gregory Palamas, je teoretickým základom konceptu božskej korelácie hypostázy a Sophie, ktorý bol rozpracovaný vo filozofii V. S. Solovjova. Špeciálny ontologický status Sophie a jej energetická podstata spôsobuje vytvorenie harmonického a celostného života, ktorému pridáva aj výnimočnú hodnotu.
\end{abstract}

Klúčové slová: tradícia hesychazmu, božská energia, ontologická podstata filozofie "jednoty"

The influence of Byzantine cultural and intellectual tradition on Russian culture was complicated and inconstant. According to researchers, it is possible to observe both stages of direct influence by Byzantium and periods of refusing Byzantine heritage in the history of formation of Christian culture in Slavic lands. Nevertheless, the importance of Byzantine culture for Russian lands was remarkable. Thus, in the article "Religious and Moral Conditions of Russian Society before Peter the Great's Reform" Vladimir Solovyov wrote about the literary records of Byzantium, stating that they were "for us both literary samples, and sources of intellectual and moral culture".

The matter of high interest is not only the discovery of direct influence examples of the Byzantine tradition in Russian culture, which is already quite well described in literature, but also the study of complex indirect intellectual influences, ideals and images that helped to shape the Russian philosophy.

СОЛОВЬЕВ, Владимир Сергеевич. Религиозно-нравственное состояние русского общества пред реформой Петра Великого. Санкт-Петербург 1878, p. 4. 
For the Russian medieval tradition, hesychasm was not only theological doctrine that had to be a vital basis of the moral way of life, promoting the ideal of Christian type of behavior, such as ascetic behavior. The theologian Georges Florovsky, while characterizing Old Russian spiritual development, notices that its "flaws and weaknesses consist partly in the insufficiency of ascetic temper (and absolutely not in the excess of austerity), in insufficient „spirituality “ of soul, in excessive „warm-heartedness“, or „poetry“, in a spiritual formlessness of the mental element. Perhaps, in spontaneity“. 2

Of course, first of all, special interest in hesychasm was shown by intellectual elite of that time - monkhood - as hesychasm offered the principles on which the daily practices of monastic life could be based. The thesis about the possibility of the knowledge of God, the actual housel with God, approved in the 15th century as a result of a dispute between Barlaam and Gregory Palamas on the ontological nature of the light of the Mount Tabor, had special value for formation of mystical theology. V. Lossky quoted Gregory Palamas' idea about the possibility of the knowledge of God in a thesis: „the God's essence isn't accessorial and is to some extent accessorial. We housel the Divine nature, and at the same time it doesn't housel at all".3 Declaring two modes of life of God - essence and energy, Palamas, according to Vladimir Lossky, offers a doctrine about divine energies that "doesn't break divine simplicity in any way if only this simplicity doesn't turn into a philosophical concept by which indefinable is attempted to be determined". ${ }^{4}$ Palamas formulates the idea of such relation to the world and God, in which the undoubted value of a knowledge of God was approved by forms of personal action, a clever prayer which is, finally, allowed to create an image of harmonious life of the Christian (first of all, the monastic). This image did not have only speculative appeal, but was a specific reference point of daily activity, setting ideals and norms of Christian life.

Thus, it is possible to define some key ideas of a palamism that defined its influence on Russian culture of the middle Ages:

1. Acceptance of fundamental Palamas' idea of distinction of divine essence and divine energy by Russian thinkers. The ontological status of divine energy is fairly articulated.

2. Understanding of a human nature through the light of the Mount Tabor, inherent to the human's ontology. At least two main conclusions derive from this thesis:

a) Understanding of privity of the human and the divine (in potentiality and in probable actualization);

b) Understanding and articulation of the importance of personal ascetic way of life - first of all, monastic way of life. Thus, a question of interpersonal Christian interaction that has to strengthen both the particular Christian person and Christian community is arising from necessity. Sergey Horuzhy notes that the tradition of monasticism assumes that monks "leave a society to act out a deed of creating a new mystical society, consolidating all mankind, but by other, new bonds - by love and prayer".

Whether these principles of interaction in such mystical society could exist was a question actively discussed by Russian hesychastes. Assuming that hesychasm implies the way of personal orientation to God by the means of silence, enlightenment, Jesus prayer, Nilus of Sora, one of the best

ФЛОРОВСКИЙ, Георгий Васильевич. Пути русского богословия. Москва 2009, p. 15.

3 ЛОССКИЙ, Владимир Николаевич. Паламитский синтез. In Богословские труды. Сборник, посвященный Владимиру Лосскому. vol. 8, 1972, p. 197.

4 ЛОССКИЙ, Паламитский синтез, р. 197.

5 ХОРУЖИЙ, Сергей Сергеевич. Владимир Соловьев и мистико-аскетическая традиция православия. In Богословские трудьь, vol. 33, 1997, p. 235. 
known hesychastes of medieval Russia, speaks about the preferability of an „average, „regal“ way“ in implementation of righteous life. Modern Russian researcher G.M. Prokhorov pays attention to one phrase from Nilus of Sora's Statute: „if there is somewhere a spiritual elder having pupils, one or two, and if sometimes he has a need for a third, and those nearby keep silence in appropriate time, coming to each other they are enlightened by spiritual conversations ". ${ }^{6}$ It testifies that, in Nilus of Sora's Statute, understanding of tradition of hesychastic privacy and ascesis quite fits into the Byzantine tradition, supplementing it with a new understanding of the issues of collective devotion.

The special role of hesychasm in Russian medieval culture was shown through a prism of that moral potential which was born from activity of the most outstanding hesychastes. They certainly embodied a Christian ideal of personal improvement, and, at the same time, their activity is considered in the context of the social importance of their acts. It is Sergey of Radonezh, whose name is connected with formation of the Russian spiritual ideal and the phenomenon of the Russian spiritual culture, Andrey Rublyov, the greatest icon painter of the Moscow school of iconography. A special place among hesychastes of medieval Russia is taken by Nilus of Sora who was the voicer of ideas of the Non-possessors Movement, major aspect of which was following a Christian austerity, refusal of material well-being in the world. All these examples testify to a specific assimilation of ideas of hesychasm, combination both of a personal austerity and spiritual improvement with care for the perfection of the world. Georges Florovsky, characterizing the special status of hesychasm in the Russian culture, writes that their way was a path into „overcoming of the world through transfiguration and education of the new person, through formation of the new personality. This path can also be called a path of cultural creation...".7

It should be noted that the ideal of Christian devotion, apprehended and developed by the Russian hesychasm and confirmed with their personal destinies, had special value not only for medieval Russia, where they are perceived in settled semantic coordinates of Christian values. Certainly, this ideal defined in many features the ethic searching of the Russian religious philosophy in the $19^{\text {th }}$ century.

The most important aspect of formation of the Russian religious philosophy in the $19^{\text {th }}-$ the beginning of the $20^{\text {th }}$ century is the statement of the undoubted bases of human life. It is the characteristic feature of the Russian religious philosophy about which S. Frank wrote, defining it as „an ontologism of the Russian philosophy“. S. Frank, explaining the essence of ontologism, notes the following: „Not the eagerness to God, but the life in God makes an essence of this religious ontologism. ${ }^{\text {" }}$ Manifestation of this approach in the Russian religious philosophy is not accidental. Considering the synthesis of ratio and logos the major task, Russian philosophers did not consider the spiritual affinity simply a question of theology and orthodox culture. In fact, understanding as its crucial thesis the statement „sum ergo cogito", the Russian religious philosophy declares it an absolute reference point for creation of any philosophical concepts. It is not only the answer to the question about the first principles of life, it is equally a solution of the eternal problem of value-essence of life, resolution of a question of final and unconditional limits of value and semantic grid of all real.

6 ПРОХОРОВ, Гелиан Михайлович. „Общительное/общежительное безмолвие“ Иннокентия Комельского: полемика с Нилом Сорским? In Труды отдела древнерусской титературы, vol. 56, 2004, p. 269.

7 ФЛОРОВСКИЙ, Пути русского богословия, р. 25.

8 ФРАНК, Семен Людвигович. Русское мировоззрение. In ФРАНК, Семен Людвигович. Духовные основы общества. Москва 1992, р. 482. 
For the Russian philosophy of the second half of $19^{\text {th }}$ - the beginning of the $20^{\text {th }}$ centuries, the appeal to ontology is not a problem of internal consistency of descriptive model, it is a problem of definition of ultima ratio in searching for the uniform value basis, which would be able to stop the disintegration of matters of social life. Hamlets" „the time is out of joint... "is most suitable for description of the feelings of upcoming social disaster. Russian religious philosophers' choice of methodological strategy allows to comprehend the individual life of the person as „belonging to universal being and taking roots in it ... the feeling of our deep life, which at the same time, objective, supra-individual and self-evident".

V. S. Solovyov undertook the creation of a complete philosophical system, quite different - in its bases and intentions - from the European philosophical doctrines that were developed for this time, primarily by Kant and Hegel. Defining priorities of his philosophy, V. S. Solovyov justified an ontological validity of knowledge: „entity or supra-entity, determined by us as the absolute beginning of any Being, is the first Supreme principle of organic logic and, as this logic is the first basic part in philosophical system of integral knowledge, this beginning is certainly the first principle of all our philosophy" ${ }^{10}$

The idea of connection of ontological, axiological, moral and practical aspects of Christian life in integral semantic space finds full expression in the philosophy of the "All-Unity" by V. S. Solovyov. In order to resolve the task of creation of the harmonious philosophical and religious concept, he carries out a complex synthesis of the philosophical ideas, cultural intuitions and religious views of that time.

It is necessary to pay attention to two aspects of philosophy of V. S. Solovyov, which allow to find the consonance of both ideas and meanings of philosophy of the "All-Unity" and the ideas of hesychasm. First, the concept of Sophia, which is one of the key aspects of Solovyov's philosophy of the „All-Unity“, has a special ontological status. In fact, Solovyov asserts Sophia as the God, approving it as the Divine Being. It is the fourth hypostasis which isn't possessing own life, and created by will and love of three divine Hypostases' essence. There is nothing in her, but such quality arises from three divine Hypostases' essence. Sophia - in aspect of its ontological status - can be considered the intermediary between God and the created world. For this reason it is unified and multiple, bears in itself divine and created nature at the same time. Plurality of Sophia is affected by the power of unity, Logos - the acting and active beginning of unity. Solovyov calls Sophia "the Deity matter", the "God's body" embodying the God-mankind. Thanks to Sophia, the whole world finds value context as it is imbued within Sophia, animate soul of this world, the source of which is God.

The second important concept is the concept of „the God-mankind“ introduced by Solovyov. To reiterate, for hesychastic tradition the problem of an embodiment of a Christian ideal is solved by each individual Christian through their ascesis, Christian life and self-sacrifice. For Solovyov, the importance of a Christian ideal is indisputable, in this regard he stays in the context of the ideas implanted in the Russian culture, ideas of ascesis and genuine Christian life, the embodiment of which he was. For Solovyov's philosophy of the "All-Unity", the question of possibility of overcoming the aloofness of the created being and return of the mankind to the Absolute bosom is crucial. Determining quality of such return, he believes, is that it can be fulfilled by following Christian ideals and moral self-improvement, not for the individual person, but all mankind, purpose of which is the transfiguration achieved not by separate individuals, but by integrated subject, i.e. by the God-mankind. In fact, the God-mankind is the changed mankind.

ФРАНК, Русское мировоззрение, р. 481.

10 СОЛОВЬЕВ, Владимир Сергеевич. Критика отвлеченных начал. In СОЛОВЬЕВ, Владимир Сергеевич. Сочинения в 2- томах, Tom. II. Москва 1988, р. 215. 
The God-mankind can come to existence as the integrated subject, purpose of which is the moral self-improvement on the basis of Christian love, which has to become a basis of cultural creativity on the way of transfiguration. The God-mankind is Sophia incarnate; its transfiguration becomes possible thanks to Sophia, which provides it with ontological and axiological dimension thanks to the participation in God.

In our understanding, in the process of comparison of hesychastic tradition and V. S. Solovyov's "All-Unity“ philosophy, it is difficult to talk about direct inclusion of the ontological principles formulated by Gregory Palamas in V. S. Solovyov's philosophy. But indirect influence caused by cultural tradition of perception of hesychasm in the Russian culture leads to similarity of ideas in uniform understanding of issues of a knowledge of God in ascension of a human's spirit to divine.

\begin{abstract}
SUMMARY: GREGORY PALAMAS' ONTOLOGY AS THEORETICAL FOUNDATION OF AXIOLOGICAL ASPECTS OF THE PHILOSOPHY OF „ALL-UNITY“. The influence of hesychastic traditions on the Russian culture can be found in cultural practices beginning from the 15th century. In the 19th century the tradition of hesychasm indirectly influenced the formation of an ontological aspect of the philosophy of "All-Unity". This religious philosophy is aimed at exploring the idea of organic unity of being, unity of God and the world. The idea of distinction of divine essence and divine energy offered by Gregory Palamas can be considered as the theoretical source for the concept of the three divine Hypostases' and Sophia's correlation developed by V. S. Solovyov. The special ontological status of Sophia, its energies' nature, not only promotes creating harmonious and complete comprehension of being in the philosophy of „All-Unity”, but also gives to this life a special value status. Quotations were translated by I. Kletskova.
\end{abstract}

Doc. PhDr. Iryna Kletskova, PhD.

Byelorussian State University

The Faculty of Philosophy and Social Sciences

Philosophy of Culture Department

Kalvaryiskaya 9

220004 Minsk

Belarus

kletskova2004@mail.ru

Doc. PhDr. Anatoliy Lyahchylin, PhD.

Byelorussian State University

The Faculty of Philosophy and Social Sciences

Philosophy of Culture Department

Kalvaryiskaya 9

220004 Minsk

Belarus

philcult@bsu.by 